\title{
State Government Budgets and the Recovery Act Katharine Bradbury
}

\begin{abstract}
:
State and local governments, with revenues reduced sharply by the recession, are responding by cutting services, increasing tax rates, and drawing down reserves; they are also receiving some relief in the form of stimulus funds provided by the federal government. The stimulus funds legislated in the American Recovery and Reinvestment Act only partly offset the recession-induced shortfalls and are scheduled to phase out before most analysts believe state and local governments will see fiscal recovery well underway. Thus, observers are concerned that the state-local sector will create a substantial drag on the overall economy during fiscal year 2011 and into 2012. This brief compiles data on state gaps, responses, and stimulus funding nationwide and discusses potential implications for the national economy.
\end{abstract}

Katharine Bradbury is a senior economist and policy advisor at the Federal Reserve Bank of Boston. She is grateful to Charu Gupta for research assistance and to Bob Triest and Jeff Fuhrer for comments on an earlier draft. This brief is based on materials presented in briefings to the president and directors of the Federal Reserve Bank of Boston in the summer and fall of 2009. It has been updated to incorporate more recent data and analysis.

The views expressed in this brief do not reflect an official position of the Federal Reserve Bank of Boston or the Federal Reserve System.

This version: February 17, 2010 
State and local governments have been hit hard by the recession. They are responding to recession-induced budget gaps by cutting services, increasing tax rates, and drawing down their reserves, and are also receiving some relief in the form of stimulus funds provided by the federal government via the American Recovery and Reinvestment Act (ARRA). These funds transferred to states stimulate the national economy by reducing the extent of pro-cyclical actions (tax increases and cuts in spending and services) that state and local governments would otherwise be required to take to balance their budgets. In this way, they preserve jobs in both the public and private sectors and maintain household incomes. However, the stimulus funds only partly offset the shortfalls and are scheduled to phase out before most analysts believe state and local governments will see fiscal recovery well underway. As a result, there is concern that the state-local sector will create a significant drag on the U.S. economy beginning in fiscal year 2011.

This policy brief documents the record-setting decline in state tax revenues that occurred nationwide as the economy fell into recession in 2008 and 2009 and reports the overall size of state budget gaps that emerged in fiscal year (FY) 2009, which ended in June 2009 for most states. It describes several provisions of the Recovery Act aimed at the state-local sector and the role those provisions played in offsetting FY2009 budget gaps. State and local government budget gaps tend to persist even after economic recovery is under way when the labor market recovery is delayed (as it was after the last two recessions and shows evidence of being this time). The gaps to date in FY2010 - and those expected in FY2011 (for which governors are now proposing budgets) - are larger than those in FY2009. While more ARRA funding is available in FY2010 than in FY2009, less is currently obligated for FY2011 (and much less for FY2012). The policy brief concludes by examining estimates of the stimulative effects of Recovery Act funds and resulting concerns regarding the likely negative effects-on both growth in the overall economy and the wellbeing of residents-of adjustments states will be forced to make as stimulus funds run out. 


\section{Cyclical revenue shortfalls}

From a macroeconomic vantage point, one key characteristic of U.S. state and local governments is that almost all of them are required to adopt balanced budgets. Tax revenues, which are generated by economic activity, tend to move pro-cyclically; as a result, budgetbalancing by state and local governments tends to amplify national business cycle swings. Figure 1 shows steep year-over-year declines in state tax revenues nationwide in the four most recent quarters with available data (through the third calendar quarter of 2009). For the 50 states combined, the 16-percent year-over-year decline in total tax revenue in the second quarter was the worst on record (going back almost 50 years); the steepest drops occurred in individual income taxes, which account for more than one-third of state tax revenues nationwide. While the decline in the third quarter was smaller, the bulk of collections occur in the second quarter because of April filing deadlines for individual income taxes. For state fiscal year 2009 (four quarters ending in Q2 2009), the nationwide tax revenue decline amounted to $\$ 63$ billion. Data for the fourth quarter of 2009 are not yet available, but early indications are that they will show further declines from a year earlier. ${ }^{1}$ Revenue losses like these would require severe cuts in spending by state and local governments if no other responses were possible.

\section{Budget gaps in state fiscal year 2009}

Analysts who study the state-local sector focus on "budget gaps," or deficits that would occur if states were not required to eliminate them before they happen. The declines in tax revenue shown in Figure 1 represent a first-round indicator of such gaps; in addition, gaps reflect declines in non-tax revenue sources (such as fees) and increased needs for public services and government transfers in a weak economy. The Center on Budget and Policy Priorities (CBPP) has compiled states' estimates of their budget gaps (see McNichol and Johnson, 2010). In fiscal year 2009 (running from July 1, 2008 through June 30, 2009 for most states), substantial

1 Dadayan and Boyd (2010) report that "preliminary figures for October and November for 38 earlyreporting states show continued but less dramatic revenue declines" (p. 1). 
gaps developed. ${ }^{2}$ Some shortfalls surfaced-and were addressed-between the time when governors proposed their budgets and state legislatures adopted them, and considerably more developed once the fiscal year was under way and the economy began deteriorating more sharply. The shortfalls totaled $\$ 110$ billion across the 50 states in state fiscal year 2009, amounting to about 15 percent of nationwide state government general funds.

States eliminate their gaps to arrive at a balanced budget by some combination of three policy options: cutting spending and services, increasing taxes, and drawing down reserves. In addition, the stimulus bill-adopted in February 2009 (more than halfway through states' 2009 fiscal years)-provides a fourth type of gap-filler. FY2009 gaps were addressed more by spending cuts and drawing down reserves than by tax increases, at least in part because the economy and revenue situation deteriorated so rapidly that they did not have time to develop and implement their tax-increase options. States enacted revenue increases amounting to \$1.5 billion, reduced their year-end balances by an estimated $\$ 27.1$ billion, and cut general fund spending from FY2008 by $\$ 31.3$ billion. ${ }^{3}$ As discussed in the next section, ARRA transfers from the federal government provided about $\$ 30$ billion of fiscal relief for states' FY2009 budgets.

\section{ARRA: stimulus funding for state and local governments}

The stimulus bill-the American Recovery and Reinvestment Act (ARRA) - provides funds for states in their fiscal year 2009-2012 budgets. The two biggest pieces of Recovery Act funding for state governments are intended to provide fungible fiscal assistance, allowing states to use the funds to offset broad revenue shortfalls. They include an increase in the federal matching rate for state Medicaid spending (FMAP) and the State Fiscal Stabilization Fund (SFSF), administered through the Department of Education. FMAP funds are intended for Medicaid, and the SFSF for state aid to schools, but since these are programs the states would otherwise be funding from general revenues, the federal funds can free up money to prevent cuts in other state programs, as well. Over the entire stimulus horizon, this general fiscal relief

${ }^{2}$ Most (46) states' fiscal years begin on July 1 and end on June 30; the federal fiscal year, by contrast, runs from October 1 through September 30.

${ }^{3}$ Net changes for FY2009 from National Governors Association and National Association of State Budget Officers, December 2009. 
totals over $\$ 140$ billion (see top panel of Table 1 ).

The other stimulus dollars flowing to state and local governments are earmarked for specific projects or programs (middle panel of Table 1). The largest are for infrastructure investments - highway construction and other transportation, amounting to about $\$ 48$ billion in total-and additional education funds focused on disadvantaged and special education students (about $\$ 25$ billion). With other earmarked state-local funds included, the total is over $\$ 90$ billion. While helpful in stimulating the economy overall, earmarked funds do not offset general state budget shortfalls. Thus, the discussion of state-local ARRA funding below focuses only on the $\$ 140$ billion of general fiscal relief coming through FMAP and SFSF. ${ }^{4}$

Looking at the period ending June 30, 2009, three-quarters of the $\$ 30$ billion of generalpurpose stimulus funds noted above that helped fill states' FY2009 budget gaps became available through the increase in the federal matching rate for Medicaid ( $\$ 22.5$ billion); the remaining $\$ 7.5$ billion came via the Education Department's State Fiscal Stabilization Fund. ${ }^{5}$ The fact that states received $\$ 30$ billion in FMAP and SFSF outlays before June 30, 2009 reveals a key advantage of these fungible Recovery Act funds in terms of their stimulative impact-their timing. One criterion for successful stimulus is how fast the funds actually move into the economy. These programs prevented cuts to state-local spending that would otherwise have occurred in FY2009-avoiding layoffs and increasing services and transfers to individuals; that is, they were "spent" as fast as the cuts would otherwise have been implemented to balance FY2009 budgets. These effects were felt sooner than even "shovel-ready" road and building projects; indeed, the 50 states saw only about a quarter of a billion dollars in infrastructure outlays from the Department of Transportation in FY2009 and only $\$ 5.6$ billion by the end of calendar year $2009 .^{6}$

4 Other than state-local, the broader Recovery Act programs include tax cuts for businesses and individuals/households, transfers to individuals/households, and direct federal spending and investment (bottom row of Table 1). General state fiscal relief amounts to about 18 percent of the total ARRA budget impact.

${ }^{5}$ Figures are total gross outlays for the 50 states and D.C. through the week ending July 3, 2009, according to agency reported data accessed through download center on the recovery.gov website.

${ }^{6}$ Budget outlays to the states for "highway infrastructure investment, recovery act" totaled only \$278 million according to agency-reported data as of $7 / 3 / 09$, accessed through the download center at 


\section{Budget gaps and ARRA in FY2010 and beyond}

Figure 2 displays the dollar amounts of budget shortfalls compiled by the Center on Budget and Policy Priorities for (state) fiscal years 2009 through 2012, and compares them with gaps states faced in the previous recession (see McNichol and Johnson, 2010). The FY2009 gaps exceed those for the years following the 2001 recession, and projected state budget gaps are even larger in FY2010 than in FY2009, amounting to \$194 billion across 48 states. ${ }^{7}$ Many states have addressed their FY2010 gaps already; others continue to work on eliminating them. In total, this year's estimated gaps represent more than one-quarter (28 percent) of states' general fund budgets.

States are using all available methods to close gaps in FY2010. At least 30 states have enacted tax increases and several more are considering them; according to The Fiscal Survey of States, the net revenue impact of these enacted changes is estimated to be $\$ 23.9$ billion in FY2010 revenues. Many states have reduced aid to local governments. Most states have cut a broad range of services, including health care, corrections, higher education, K-12 education, services to the elderly and disabled, and other programs, such as public assistance, that might otherwise have helped the most vulnerable families better weather the recession, amounting to $\$ 55.7$ billion in budget savings (according to responses regarding budget plans to The Fiscal Survey of States as the fiscal year got underway during the fall). These spending cuts involve reductions in payments to individuals, cancellation of contracts with (or reductions in payments to) businesses and non-profits, and public sector layoffs; state and local government jobs nationwide were cut by over 140,000 (0.7 percent) between the end of FY2009 and January $2010 .^{8}$

recovery.gov. While representing less than 18 percent of ARRA funds over the full period, general state fiscal relief accounted for 30 percent of ARRA outlays through the end of June 2009, according to the Council of Economic Advisers' Second Quarterly Report on "The Economic Impact of the American Recovery and Reinvestment Act of 2009," January 13, 2010, Table 2. In addition to state fiscal relief, most of the other Recovery funds that were disbursed before June 30 were payments to individuals and individual tax cuts such as the increase and extension of unemployment benefits, one-time payments to recipients of Social Security and other benefits, the Making Work Pay tax credit, and increases in nutritional assistance and TANF.

${ }^{7}$ North Dakota and Montana are not facing gaps in FY2010, at least as of January 28, 2009.

${ }^{8}$ U.S. Bureau of Labor Statistics data on payroll employment, seasonally adjusted. 
At the time of the Fiscal Survey, states were also planning to draw down reserves in FY2010, but to a lesser degree than in FY2009: "Because states recognize that this economic downturn may last into 2012, they are reluctant to deplete balances." 9

States are also using stimulus money. The Center on Budget and Policy Priorities estimates that general-purpose stimulus funds going to state and local governments are filling about 30 percent of state budget shortfalls nationwide in fiscal years 2009 through 2011, which represents a sizable offset to the even greater pro-cyclical tax raising and spending cuts that would otherwise have occurred. More specifically, slightly more than halfway through (state) fiscal year 2010 (as of January 29, 2010), the 50 states have seen an additional \$33.5 billion in direct fiscal assistance beyond the almost $\$ 30$ billion that was available in their FY2009. About 64 percent of these outlays were via augmented Medicaid matching and the remainder through the state fiscal stabilization fund. States are projected to receive a total of $\$ 68$ billion in fiscal relief during FY2010, filling about 35 percent of gaps nationwide (see Figure 3).

At least 44 states have looked ahead to FY2011 and anticipate gaps. Initial estimates put these shortfalls at $\$ 102$ billion for the 41 states that have estimated their size. In all, the Center on Budget and Policy Priorities projects at least \$180 billion in FY2011 shortfalls nationwideagain over one-quarter of state budgets. Many of the governors' budget proposals for FY2011 released in recent weeks involve significant spending cuts. ${ }^{10}$

The biggest element of ARRA general fiscal assistance to states - the elevated FMAP - is scheduled to go to zero after December 31, 2010, in the middle of most states' 2011 fiscal year. ${ }^{11}$ States have signaled to the Department of Education that most of the education funding will have been used by then, as well.12 Thus, ARRA will offset a smaller fraction of shortfalls in FY2011 than in FY2010. In FY2012, when very little general-purpose ARRA funding will be available, the Center on Budget and Policy Priorities projects shortfalls totaling about \$120

\footnotetext{
${ }^{9}$ National Governors Association and National Association of State Budget Officers, p. viii.

${ }^{10}$ See Johnson et al., February 2010.

${ }^{11}$ President Obama's budget request includes an extension of the elevated Medicaid match beyond 2010.

${ }^{12}$ Lav et al. indicate that states have reported planning to draw down 85 percent of SFSF funds by June 30,2010 , so they expect that most of the remaining 15 percent will be paid out by the end of the calendar year.
} 
billion. ${ }^{13}$

Why are states expected to continue to suffer shortfalls into fiscal 2012 even though the economic recovery is currently considered to be under way and unemployment is expected to begin moving down at the end of 2010? As the left-hand side of Figure 2 indicates, states continued to experience shortfalls for several years after the economy began to recover from the last recession; such lags occurred after the 1991 recession as well. In large part, these lags reflect the delayed recovery of employment after those recessions. High unemployment impairs family incomes and thereby keeps state revenues depressed and also causes demand for public assistance and other state-funded services to remain swollen. The need for Medicaid, for example, stays high because families often lose private health insurance along with their jobs. Because joblessness in the current recession has reached double digits, forecasters expect unemployment rates to remain elevated at least through $2012 .{ }^{14}$ Thus, the lingering effect on budget gaps is likely to be larger and longer than in the past two recessions.

\section{The economic impact of ARRA and state budget shortfalls}

As noted earlier, one determinant of the stimulative effect of policies is how fast they make their way into the economy. Three other criteria typically used in judging these impacts are bang-for-the-buck, protecting vulnerable populations, and the broader long-term value of program "outputs;" fiscal relief for state-local government scores quite well along these lines, as well as speed. Economists measure bang-for-the-buck via multipliers, indicating how many dollars higher GDP will be in response to an additional dollar from the government budget (spending increase or tax cut). One of the determinants of bang-for-the-buck is the extent to which the public spending or tax cut is targeted on people who will spend, rather than save, the additional money, since the idea is to have the dollars circulate as soon and as widely as possible. Low-income families generally spend a higher fraction of their incomes than high-

${ }^{13}$ In addition, shortfalls of local governments-municipalities, counties, school districts, and other local authorities - pose an additional challenge not tallied by CBPP.

${ }^{14}$ For example, the Federal Open Market Committee members' projections have a central tendency of 6.8 to 7.5 percent for unemployment in 2012, according to the published minutes of the meeting on November 3-4, 2009. 
income families, and this is particularly true of those whose incomes are suddenly reduced by job loss in a recession. Thus, bang-for-the-buck tends to be higher for programs that protect the neediest families - those who tend to be more vulnerable to economic downturns.

According to consensus estimates, tax cuts have lower multipliers than spending increases, with tax-cut multipliers generally below one and spending multipliers greater than one. ${ }^{15}$ The stimulative effects of the state fiscal relief elements of ARRA depend on what states would have done in the absence of ARRA. The Council of Economic Advisers projected the effects of state-local transfers by assuming that 60 percent of the transfers to states would be used to prevent spending reductions, 30 percent to avoid tax increases, and the remaining 10 percent would slow states' withdrawals from rainy-day funds. ${ }^{16}$ The 60-30 assumption implies that the average impact of ARRA state-local transfers is greater than that of tax cuts alone, but lower than pure government spending increases; along similar lines, the Congressional Budget Office estimates of the multiplier for "transfer payments to state and local governments for other [non-infrastructure] purposes" are about three-quarters the size of their estimated multipliers for direct federal spending. ${ }^{17}$

The Council of Economic Advisers estimated that overall ARRA outlays through the fourth quarter of 2009 added about 2 percent to the level of GDP and up to 2 million to employment levels. ${ }^{18}$ The report notes that those who observe ongoing declines in employment and conclude that the Recovery Act is having no effect have failed to recognize the much more negative trajectory of the economy in the absence of the stimulus. About one-fifth of the estimated ARRA-related economic improvements could be attributable to the state fiscal relief components, assuming their stimulative effects are similar, on average, to those of the other

${ }^{15}$ For examples of multiplier assumptions, see Council of Economic Advisers (May 2009) and Zandi (October 29, 2009). However, the distinction between tax cuts and spending can be arbitrary. In its "functional" categories, the Council of Economic Advisers (2010, p. 5) classified the $\$ 250$ payments to social security recipients as tax cuts and the government's subsidy of continuing health insurance benefits under COBRA (technically a business tax cut) as aid to directly impacted individuals, similar to the expansion and extension of unemployment benefits.

${ }^{16}$ Council of Economic Advisers, May 2009.

${ }_{17}$ Congressional Budget Office, November 2009, Table 2.

18 The CEA reports that these estimates fall between the "high" and "low" estimates of the Congressional Budget Office and are in line with those from private forecasters, as well. 
ARRA outlays in this period, as the previous paragraph suggests. ${ }^{19}$ This amounts to almost half a percent addition to the level of GDP and up to 400,000 jobs created or saved nationwide by the end of 2009, compared with what would have occurred without the state-local component of the stimulus.

Observers have expressed concern that the state-local sector will create a significant drag on the macro economy during FY2011 which (for states) begins this July. The overall effect of the state-local sector's budget-balancing on the economy-the degree to which it exacerbates the cyclical slowdown-will depend on the mix among state-local tax increases, spending cutbacks, reserve draw-downs, and Recovery funds in filling looming budget gaps. The multipliers apply in reverse, as well. Thus, state tax increases have a smaller damping effect on the economy than equal state spending cuts. For example, the Congressional Budget Office notes, "Without further aid from the federal government, many states would have to raise taxes or cut spending by more than they would if aid were provided. Such actions would dampen spending by those governments and by households in those states, and more state and private jobs would be lost." ${ }^{20}$ More specifically, the Center on Budget and Policy Priorities, reflecting on the shortfall estimates they have compiled and citing testimony by macro-forecaster Mark Zandi, says, "Presuming they will get no more fiscal relief, states will have to take steps to eliminate deficits for state fiscal year 2011 that will likely take nearly a full percentage point off the Gross Domestic Product. That, in turn, could cost the economy 900,000 jobs next year."21 Historically, the state-local sector has accounted for about 12 percent of GDP and added about one-quarter of a percentage point to annual GDP growth on an ongoing basis; if the sector slips back into negative territory, especially if it happens as soon as this summer, it could contribute to a reversal of the still-fragile recovery.

\footnotetext{
19 The CEA report shows state fiscal relief comprising 30 percent of ARRA outlays through June, 24.5 percent through September, and 22.5 percent through December. This declining share reflects the timing advantage of state fiscal relief discussed earlier.

${ }^{20}$ Congressional Budget Office, January 2010, pp. 23-24.

${ }^{21}$ Lav et al., p.1.
} 


\section{References}

Congressional Budget Office. 2009. “Estimated Impact of the American Recovery and Reinvestment Act on Employment and Economic Output as of September 2009." November.

Congressional Budget Office. 2010. “Policies for Increasing Economic Growth and Employment in 2010 and 2011." January.

Dadayan, Lucy, and Donald J. Boyd. 2010. “Recession or No Recession, State Tax Revenues Remain Negative." Nelson A. Rockefeller Institute of Government State Revenue Report (78) January.

Download Center at Recovery.gov, electronic data files.

Elmendorf, Douglas W. 2009. Letter dated March 2 to Senator Charles E. Grassley, reporting Congressional Budget Office's year-by-year estimate of the economic effects of the American Recovery and Reinvestment Act of 2009 (ARRA, Public Law 111-5).

Council of Economic Advisers, Executive Office of the President. 2009. “Estimates of Job Creation from the American Recovery and Reinvestment Act of 2009." May.

Council of Economic Advisers, Executive Office of the President. 2010. "The Economic Impact of the American Recovery and Reinvestment Act of 2009." Second Quarterly Report, January 13.

Federal Open Market Committee. 2009. “Summary of Economic Projections.” published with minutes of the meeting on November 3-4.

Johnson, Nicholas, Erica Williams, and Phil Oliff. 2010. “Governors' new budgets indicate loss of many jobs if federal aid expires." Center on Budget and Policy Priorities, February 5.

Lav, Iris J., Nicholas Johnson, and Elizabeth NcNichol. 2010. “Additional federal fiscal relief needed to help states address recession's impact." Center on Budget and Policy Priorities, updated January 28.

McNichol, Elizabeth, and Nicholas Johnson. 2010. "Recession continues to batter state budgets; state responses could slow recovery." Center on Budget and Policy Priorities, updated January 28.

National Governors Association and National Association of State Budget Officers. 2009. The Fiscal Survey of States. December.

U.S. Bureau of the Census. 2010. Quarterly Summary of State and Local Government Tax Revenue, Table 3, State government tax collections by state and type of tax; downloaded from http://www.census.gov/govs/www/qtax.html (accessed January 20, 2010).

Zandi, Mark. 2009. “The Impact of the Recovery Act on Economic Growth.” written testimony before the Joint Economic Committee. October 29. 
Table 1.

Advance Estimates of Budget Outlays for ARRA

(billions of dollars)

\begin{tabular}{|c|c|c|c|c|c|}
\hline \multirow[b]{2}{*}{ ARRA Program } & \multicolumn{5}{|c|}{ Federal fiscal years } \\
\hline & 2009 & 2010 & 2011 & $\begin{array}{r}2012 \text { and } \\
\text { beyond }\end{array}$ & $\begin{array}{l}\text { Total } \\
2009- \\
2019\end{array}$ \\
\hline \multicolumn{6}{|l|}{ Flexible/fungible state fiscal relief: } \\
\hline Medicaid/State Fiscal Relief (FMAP) & 33.9 & 43.9 & 11.8 & 0.4 & 90.0 \\
\hline State Fiscal Stabilization Fund (education) & 6.5 & 28.4 & 16.1 & 2.7 & 53.6 \\
\hline Fiscal Relief to State \& Local Governments & 40.4 & 72.3 & 27.9 & 3.1 & 143.6 \\
\hline \multicolumn{6}{|l|}{ - State-local earmarked/specific purposes: } \\
\hline Highway construction \& other transportation & 5.0 & 9.4 & 8.8 & 24.8 & 48.1 \\
\hline Education-related (beyond SFSF)* & 1.2 & 11.9 & 10.9 & 1.1 & 25.2 \\
\hline Housing assistance, clean water, law enforcement & 1.0 & 4.3 & 5.7 & 6.5 & 17.6 \\
\hline Earmarked Funds to State \& Local Governments & 7.3 & 25.6 & 25.4 & 32.5 & 90.7 \\
\hline $\begin{array}{l}\text { Remainder of ARRA, including transfers to individuals \& } \\
\text { households, tax cuts to individuals \& households, tax cuts \& } \\
\text { incentives to businesses, and direct federal spending \& investment }\end{array}$ & 137.3 & 301.5 & 81.1 & 32,9 & 552.7 \\
\hline
\end{tabular}

* including education for the disadvantaged and special education

Source: Author's calculations based on Douglas W. Elmendorf's letter dated March 2, 2009 to Senator Charles E. Grassley, reporting Congressional Budget Office's year-by-year estimate of the economic effects of the American Recovery and Reinvestment Act of 2009 (ARRA, Public Law, 111-5). 


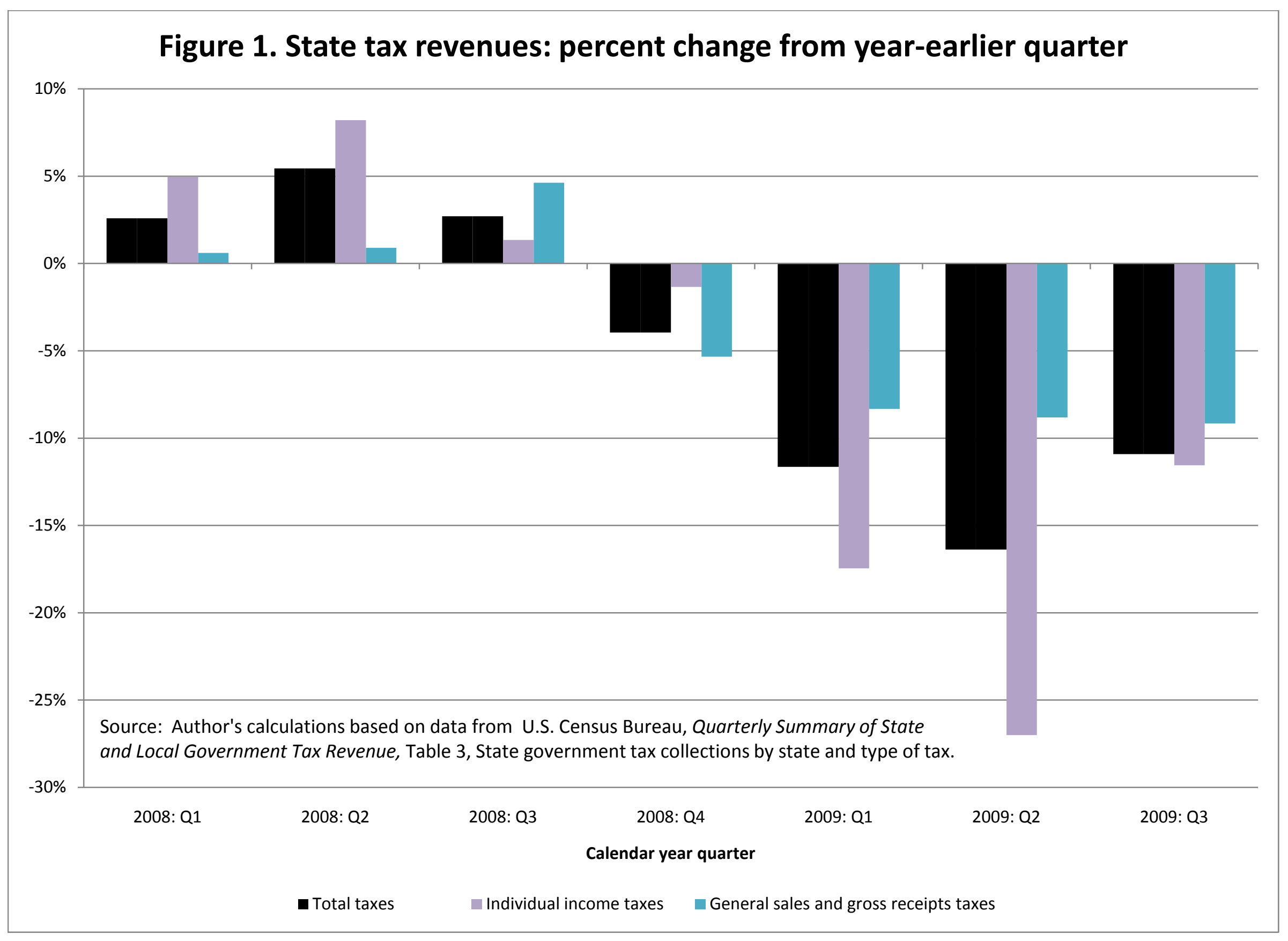



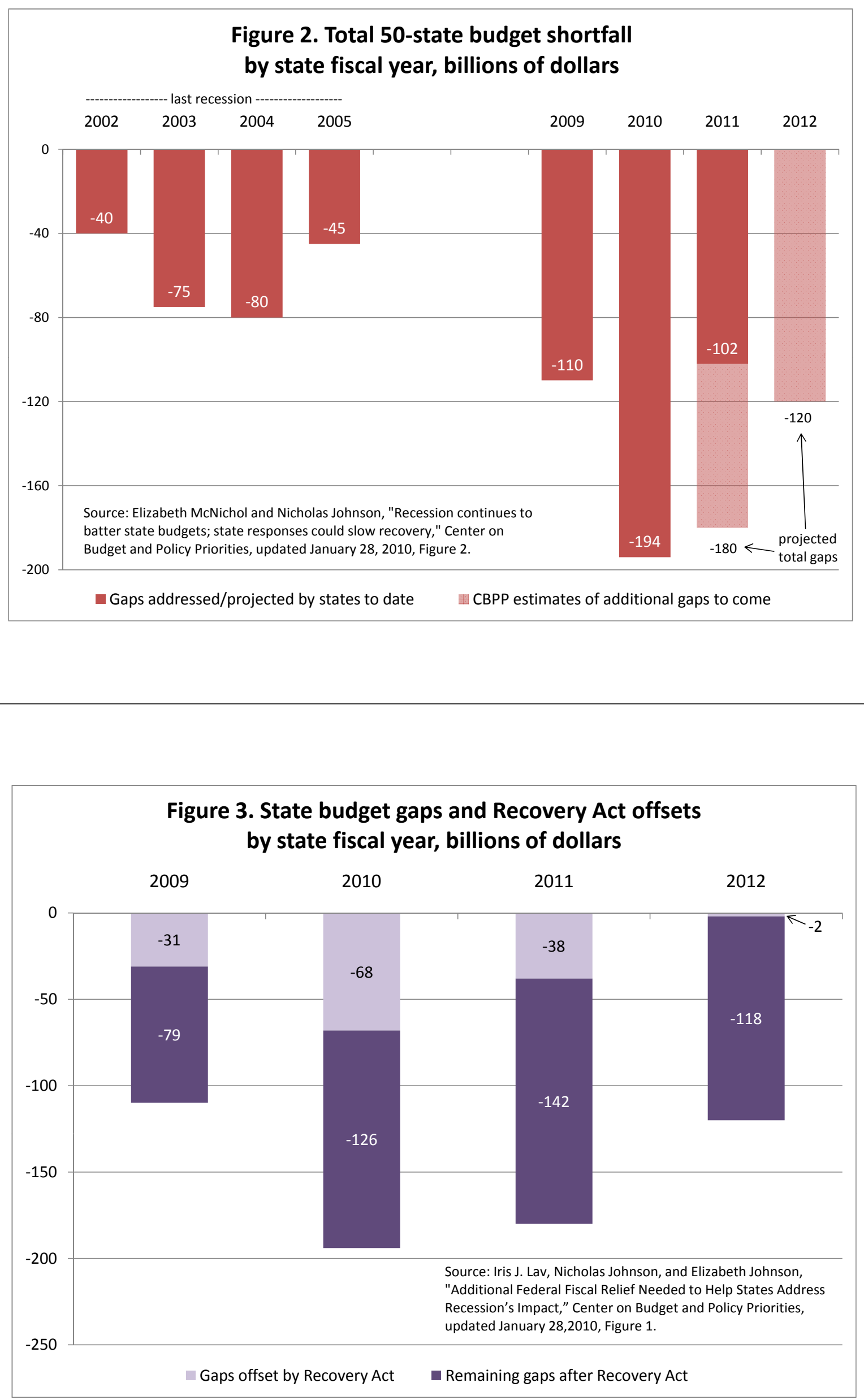